\section{Le style c'est l'homme}

\section{Walter Gratzer}

Contrasts in Scientific Style: Research Groups in the Chemical and Blochemical Sciences. By Joseph S. Fruton. American Philosophical Society: 1990. Pp.473. $\$ 40$.

Historians are apt to justify their calling by recourse to the old saw that those who do not learn the lessons of history are fated to relive them. Joseph Fruton's account of the tensions and conflicts that lay beneath the heady triumphs of chemistry during its golden heyday in Wilhelmine Germany invites inevitably the comparison with the rise of molecular biology in our own time. The same faint odour of venality spread through the universities, for instance, as the prospects of commercial exploitation drew nearer; the same surly resentments sprang up in the breasts of research students, serving a tyrannical master in the first organized research teams.

There are also undeniably differences. Even the most olympian of German professors plied his trade at the bench - the first among unequals. Robert Bunsen, one of the giants of his (or any) time, according to a contemporary quoted by Fruton, "occupied himself very actively with beginners. $\mathrm{He}$ showed them each manipulation and everything involved in an analysis." And here is W. H. Perkin's recollection of Adolf von Baeyer in action: "It was [my] good fortune to be allowed to take part and watch these experiments, and the experience of the experimental skills with which Baeyer carried out these very ticklish operations [the synthesis of a series of explosive acetylene compounds], with no other apparatus than testtubes and glass rods, is to this day a very lively recollection."

Fruton's purpose is to explore how the relations that the head of a research group establishes with the workers in his charge relates to the success of the enterprise. The first of the titans, who deployed a small army of workers with its rigorously defined chain of command to overwhelm the chosen sector of his science, was Liebig. His laboratory at Giessen prefigured the type of operation now commonplace at Caltech and MIT, except that supervision was closer than Liebig's modern inheritors would regard as feasible or today's students and postdocs as tolerable. Liebig harrried his students ceaselessly; Fruton quotes a passage from his memoirs, which concludes: "We worked from daybreak until nightfall, distractions and diversions were not available in Giessen." Even his practice - unusual at that time - of sometimes allowing his students to publish work under their own names in his house journal, the Annalen, was calculated: "The people who work with me", he confided to one of his associates, "publish under their own names, even if I have helped them. If it is something good, a part of the credit is ascribed to me and I do not need to defend the mistakes. You understand?" It was indeed arguably more important to have been a Liebig Schüler than to have done work of substance.

By contrast, Hoppe-Seyler, intolerant and contentious as he famously was, showed exemplary generosity and loyalty towards his associates. Hofmeister was another whose patronage was warm and disinterested. Baeyer, who built up the most influential research school of his time, emerges as an awesome, yet inspiring figure, one whose approval was most eagerly sought. Legends sprang up about him; Fruton eschews the more frivolous anecdotes, but it seems a pity that he denies his readers the vision of the Old Man's delight when the crystals of the first terpene appeared in the tube, and the famous bowler, which left his head only in rare moments of high emotion, was raised twice in salute.

Baeyer's greatest and unswervingly devoted student was Emil Fischer, an austere and unattractive personage and a despot when he acceded to his own research group. Fruton believes that his unforthcoming character may have owed much to the ravages of chronic chemical poisoning, for he had exposed himself continuously and in an illventilated laboratory, to phenylhydrazine and to volatile mercury compounds. There is also here a description of Fischer's first effort as a graduate student, which must surely have left a spiritual scar: he was required to effect the reduction of half a kilogram of mel- litic acid with sodium amalgam - made from no less than 25 kilograms of mercury. He was carrying the flask that contained his hardwon product when the floor of the laboratory gave way and the whole lot was lost.

Fruton traces the complex and uneasy relation between organic chemistry and biochemistry, or physiological chemistry (Schmierchemie to the purists) as it was then called, and the kinds of cul-de-sac in which so many of the early efforts ended. "How little of what I learned with great pains", Otto von Fürth wrote poignantly, "has importance today, and how many of the problems that the previous generation of physiologists fought about so passionately have lost for us any sense or significance."

The last chapter of Fruton's magisterial work brings the story, by way of Gowland Hopkins, Warburg and Krebs to the biochemistry and molecular biology of the present day. It ends with 140 pages of appendices, in which are recorded the names of all those (so far as Fruton's excavations of the archives are able to determine them) who toiled at some time in the seven great laboratories that serve as his exemplars. Here are gathered the celebrated and the obscure men (nowomen) who became professors, industrial chemists, shopkeepers and landowners - here one who fell at 30 in the Great War, there an octagenerian, who perished in Theresienstadt. It is a memento mori and a monument to the foot-soldiers of science; let us hope that one day a successor of Joseph Fruton's will do the same for us.

Walter Gratzer is in the MRC Muscle and Cell Motility Unit, King's College, Drury Lane, London WC2B 5RL, UK.

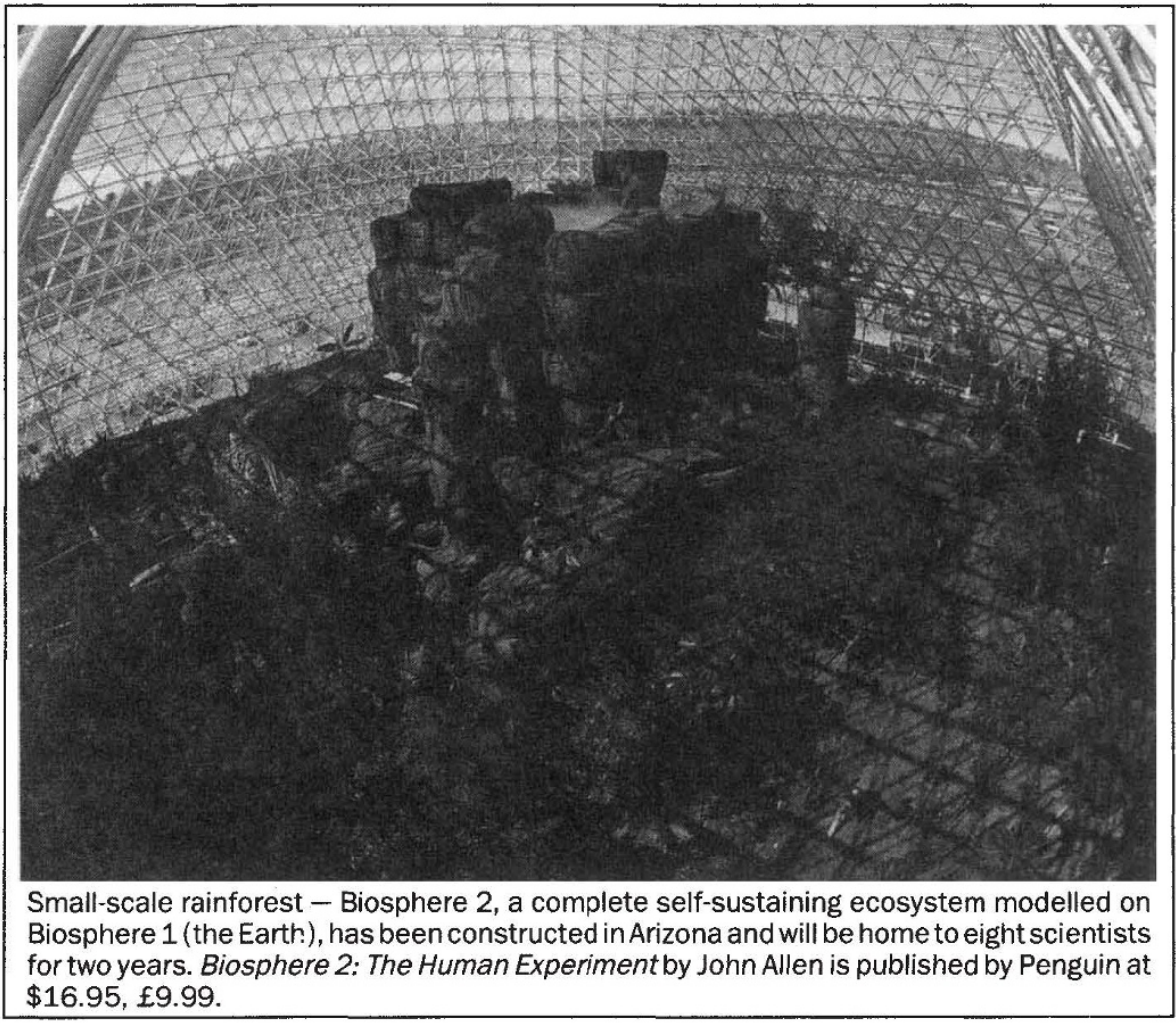

